\title{
Long-term efficacy of Boswellia serrata in 4 patients with chronic cluster headache
}

\author{
C Lampl $^{1 *}$, B Haider $^{2}$, C Schweiger $^{3}$ \\ From The European Headache and Migraine Trust International Congress \\ London, UK. 20-23 September 2012
}

\section{Background}

Cluster headache $(\mathrm{CH})$ is an extremely severe and debilitating trigemino-autonomic pain syndrome.About $10 \%$ of patients with $\mathrm{CH}$ manifest a chronic form $\mathrm{CH}(\mathrm{CCH})$. Extracts of Boswellia serrata have been clinically studied for the treatment of many inflammatory conditions such as osteoarthritis and rheumatoid arthritis (3). The resin from Boswellia Serrata contains a number of biological actives called pentacyclic triterpene acids, which give the extract its anti-inflammatory and analgesic properties, with boswellic acid the major active ingredient (4). These acids have been demonstrated to interfere with the body's natural inflammatory response by inhibiting cytokines and leukocyte activity. The present study aims to evaluate the long-term efficacy of Boswellia Serrata (Sallaki H15) on headaches and disturbed sleep in patients with $\mathrm{CCH}$.

\section{Results}

In an open-label study, 4 patients with $\mathrm{CCH}$ and disturbed sleep received oral Boswellia Serrata.

\section{Conclusion}

The effects were long-lasting in 3 patients (mean 15 months) and transient (6 months) in one patient. The rapid improvement of nocturnal pain within weeks is similar to the analgetic effect observed in recent trials using Boswellia Serrata in cancer pain The mechanisms of how Boswellia Serrata reduces pain in $\mathrm{CCH}$ remain unclear. Boswellic acids, constituents of Boswellia extract have subsequently been identified as selective redox independent noncompetitive inhibitors of both 5-lipoxygenase, the key enzyme in leukotriene biosynthesis and human leukocyte elastase. Proinflammatory cytokines, such as leukotrienes, are known to play a role in the pathophysiology of $\mathrm{CH}$. This study

${ }^{1}$ Hospital of Sisters of Mercy, Linz, Austria

Full list of author information is available at the end of the article provides Class IV evidence that oral Boswellia Serrata (Sallaki H15) reduces the intensity and frequency of headaches in patients with $\mathrm{CCH}$.

\section{competing interests}

None.

\section{Author details}

${ }^{1}$ Hospital of Sisters of Mercy, Linz, Austria. ${ }^{2}$ LNK Wagner Jauregg, Linz,

Austria. ${ }^{3}$ Barmherzige Brüder Linz, Austria.

Published: 21 February 2013

References

1. Headache Classification Subcommittee of the International Headache Society: The International Classification of Headache Disorders. Cephalalgia , 2 2004, 24(suppl 1):1-160.

2. Goadsby PJ, Schoenen J, Ferrari MD, Silberstein SD, Dodick D: Towards a definition of intractable headache for use in clinical practice and trials. Cephalalgia 2006, 26:1168-1170.

3. Ammon HP: Modulation of the immune system by Boswellia serrata extracts and boswellic acids. Phytomedicine 2010, 17(11):862-867.

doi:10.1186/1129-2377-14-S1-P37

Cite this article as: Lampl et al:: Long-term efficacy of Boswellia serrata in 4 patients with chronic cluster headache. The Journal of Headache and Pain 2013 14(Suppl 1):P37.

Submit your manuscript to a SpringerOpen ${ }^{\circ}$ journal and benefit from:

- Convenient online submission

- Rigorous peer review

- Immediate publication on acceptance

- Open access: articles freely available online

- High visibility within the field

- Retaining the copyright to your article

Submit your next manuscript at $>$ springeropen.com 